\title{
Has the Nobel Prize gone to the Dogs?
}

\author{
Seun Ayoade* \\ Department of Physiology, Nigeria
}

Received: 眥 November 02, 2018; Published: 眥 November 06, 2018

*Corresponding author: Seun Ayoade, BSc (Hons) University of Ibadan, Independent Researcher, P.O. Box 22325, Nigeria

\section{Opinion}

"I, the undersigned, Alfred Bernhard Nobel, after mature deliberation, hereby declare the following to be my last will and testament about such property as I may leave upon my death. All my remaining realisable assets are to be disbursed as follows: the capital, converted to safe securities by my executors, is to constitute a fund, the interest on which is to be distributed annually as prizes to those who, during the preceding year, have conferred the greatest benefit to humankind. The interest is to be divided into five equal parts and distributed as follows: one part to the person who made the most important discovery or invention in the field of physics; one part to the person who made the most important chemical discovery or improvement; one part to the person who made the most important discovery within the domain of physiology or medicine; one part to the person who, in the field of literature, produced the most outstanding work in an idealistic direction; and one part to the person who has done the most or best to advance fellowship among nations, the abolition or reduction of standing armies, and the establishment and promotion of peace congresses. The prizes for physics and chemistry are to be awarded by the Swedish Academy of Sciences; that for physiological or medical achievements by the Karolinska Institute in Stockholm; that for literature by the Academy in Stockholm; and that for champions of peace by a committee of five persons to be selected by the Norwegian Storting. It is my express wish that when awarding the prizes, no consideration be given to nationality, but that the prize be awarded to the worthiest person, whether or not they are Scandinavian". Last Will and Testament of Alfred Nobel $27^{\text {th }}$ of November 1895. [1]

Excepting perhaps the Peace Prize, I declare that the caliber of Nobel Prize recipients is clearly and steadily headed for the sewers. This is because the Nobel Prize has been hijacked by an evil leftwing cabal. The hitherto apolitical prize has now become heavily politicized and skewed to the left. The bastardization of the prize began with the launch of economics Nobel Prize, not part of Alfred's original plan. Little wonder the caliber of winners- Paul Romer [2018 co-winner], for instance left the World Bank in a cloud of controversy. The final nail however was the award to a musician-
Bob Dylan of the literature prize. I nearly threw up when I heard the announcement. Not for any hatred of Bob Dylan, but for the bastardization of the prize. How would one feel if a motorcycle was allowed to race in the Kentucky Derby? Or if a horse was allowed to compete in the Grand Prix? Would you be okay with a basketball player put in a boxing ring? Or a speedboat in a yacht race? Literature, in the context clearly defined by Mister Nobel in his last will and testament did not include songwriting, songwriters or the sheet music makers of his day. There was never meant to be a Nobel Prize for sheet music, songwriting, performing music or proficiency in instrumentation. If Alfred Nobel had wanted it so he would have stated same in his will. Bob Dylan's award is an affront to every writer [me included] worldwide. Furthermore, there was never meant to be a Nobel Prize for drama or film. I wouldn't be surprised if a Hollywood screenplay or scriptwriter is soon given a Nobel Prize for literature. That's how whacky the world we live in has gotten. Music and sound [and even film] recording existed in 1895. Mr. Nobel had no interest in that. Alfred Nobel was an inventor and scientist, not a musician or economist or violinist. The vision of Alfred Nobel was clearly contained in the text of his will. If the international radical left wants to award honors let them set up their own prizes and leave Alfred Nobel's noble prize alone. Many deserving people have been overlooked for the Nobel Prize just because the radical left hated them or what they stood for. Take for instance the Armenian doctor/scientist who invented the MRI machine-an invention that revolutionized medical diagnosis and saved many lives. Raymond Damadian was conspicuously denied the prize. Why? Because he was a moral and religious man. We know the kind of Armenians the left-wing media like to promote. Does the word 'Kardashian' ring a bell? The moral depravity of the Nobel Committee has reached such scandalous levels that no literature prize was awarded in 2018 because of licentious assault accusations. [2,3] By the way the "scientists" of the Nobel prize committee are among the many "scientists" that continue to deny the existence of the microzymas. No surprise there. Enough is enough. The Nobel committee has strayed too far, it's time for them to come to their senses! 


\section{References}

1. Alfred Bernhard Nobel (1985) Alfred Nobel's will. The Nobel Prize.

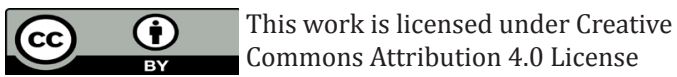

To Submit Your Article Click Here: Submit Article

DOI: $10.32474 /$ PRJFGS.2018.02.000145
2. (2018) Nobel Prize for Literature delayed amid Swedish Academy 'sex assault' scandal. BBC News.

3. Andrew Brown (2018) The ugly scandal that cancelled the Nobel prize.

\begin{tabular}{|c|c|}
\hline PF & $\begin{array}{l}\text { Peer Reviewed Journal of Forensic } \\
\text { \& Genetic Sciences }\end{array}$ \\
\hline & $\begin{array}{l}\text { Assets of Publishing with us } \\
\text { - } \quad \text { Global archiving of articles } \\
\text { - Immediate, unrestricted online access } \\
\text { - } \quad \text { Rigorous Peer Review Process }\end{array}$ \\
\hline 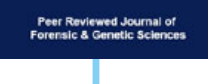 & $\begin{array}{l}\text { - Authors Retain Copyrights } \\
\text { - Unique DOI for all articles }\end{array}$ \\
\hline
\end{tabular}

